\title{
Classical triad of Kearns-Sayre syndrome
}

\author{
Akhil Kumar Sharma, ${ }^{1}$ Nirdesh Jain, ${ }^{2}$ Rajiv Bharat Kharwar, ${ }^{3}$ Varun Shankar Narain ${ }^{1}$
}

${ }^{1}$ Department of Cardiology, King George's Medical University, Lucknow, Uttar Pradesh, India ${ }^{2}$ Department of Cardiology, CSMMU (earlier KGMU), Lucknow, Uttar Pradesh, India ${ }^{3}$ Department of Cardiology, U.N Mehta Institute of Cardiology and Research Center, Ahmedabad, Gujarat, India

\section{Correspondence to} Dr Nirdesh Jain nirdeshjain8@gmail.com

Accepted 22 June 2016

\section{DESCRIPTION}

We describe the images of a 27-year-old man presenting with recurrent syncope due to complete heart block (figure 1). The patient, on further examination, showed ophthalmoplegia, bilateral ptosis (figure 2) and pigmentary retinopathy (figure 3). Kearns-Sayre syndrome (KSS) is a rare mitochondrial genetic disorder with multisystem involvement. KSS usually presents before the age of 20 years. The triad of external opthalmoplegia, pigmentary retinopathy, and cardiac conduction defects are sufficient to make a confident diagnosis of this rare entity. Cerebrospinal fluid protein of more than $1 \mathrm{~g} / \mathrm{L}$ or cerebellar ataxia are also important characteristics of KSS. There is no definitive treatment for this condition, but pacemaker implantation can prevent syncope, and reduce morbidity in patients presenting with advanced atrioventricular $(\mathrm{AV})$ conduction abnormalities.

Around $57 \%$ of patients with KSS have cardiac involvement, including recurrent syncope, bundle branch blocks, fascicular blocks and non-specific intraventricular conduction disturbances. ${ }^{1}$ Around $20 \%$ of deaths in these patients is attributed to cardiac causes. The American College of Cardiology/American Heart Association/Heart

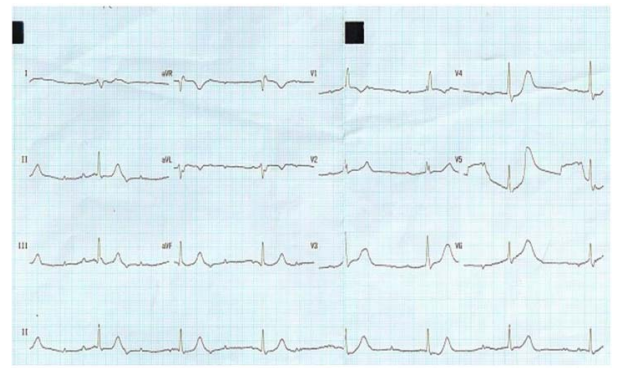

Figure 1 Twelve-lead ECG showing complete atrioventricular block with an incomplete right bundle branch block type of escape rhythm at a rate of $40 / \mathrm{min}$.

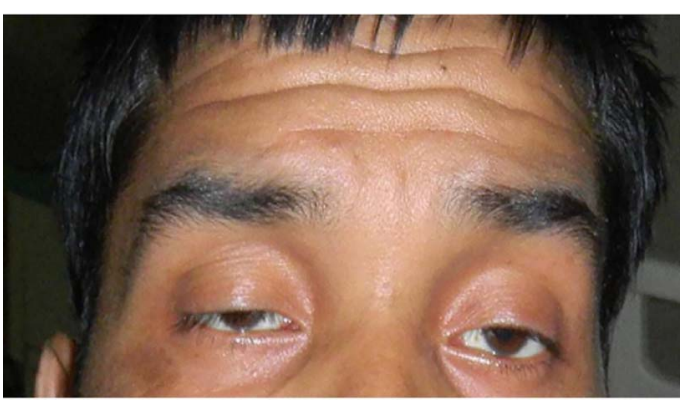

Figure 2 Photograph of the patient showing bilateral ptosis with compensatory wrinkling on the forehead.

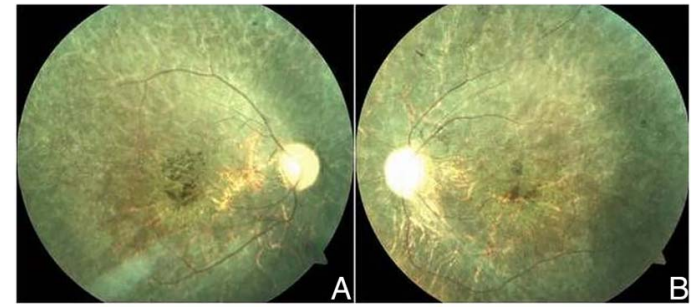

Figure 3 Fundus examination of the right and left eye showing pigmentary retinopathy.

Rhythm Society guidelines give a class I, level of evidence $\mathrm{B}$ rating to implantation of pacemakers for third-degree and advanced second-degree $\mathrm{AV}$ block at any anatomic level when associated with neuromuscular diseases and AV block.

Histopathological examination of the skeletal system characteristically shows ragged red fibres. Endocrinopathies occur commonly in these patients, and around 13\% develop diabetes. ${ }^{2}$ Although diabetes, hypothyroidism, and parathyroid disorders do occur, our patient did not suffer from these conditions; however, follow-up is needed. Ventricular dysfunction has been reported as a part of neuromuscular disease. ${ }^{3}$

\section{Learning points}

- Kearns-Sayre syndrome is the differential diagnosis when a young patient presents with cardiac conduction disorders.

- Permanent pacemaker implantation is only a part of the treatment; such patients need lifelong follow-up as they carry the risk of having ventricular dysfunction as part of their disease, and the risk is enhanced due to right ventricular pacing.

Competing interests None declared.

Patient consent Obtained.

Provenance and peer review Not commissioned; externally pee reviewed.

\section{REFERENCES}

1 Charles R, Holt S, Kay JM, et al. Myocardial ultrastructure and development of atrioventricular block in Kearns-Sayre syndrome. Circulation 1981;63:214-19.

2 Harvey JN, Barnett D. Endocrine dysfunction in Kearns-Sayre syndrome. Clin Endocrinol 1992:37:97-103.

3 Sachdev B, Elliot PM, McKenna WJ. Cardiovascular complications of neuromuscular disorders. Curr Treat Options Cardiovasc Med 2002:4:171-9. 


\section{Images in...}

Copyright 2016 BMJ Publishing Group. All rights reserved. For permission to reuse any of this content visit http://group.bmj.com/group/rights-licensing/permissions.

BMJ Case Report Fellows may re-use this article for personal use and teaching without any further permission.

Become a Fellow of BMJ Case Reports today and you can:

- Submit as many cases as you like

- Enjoy fast sympathetic peer review and rapid publication of accepted articles

- Access all the published articles

- Re-use any of the published material for personal use and teaching without further permission

For information on Institutional Fellowships contact consortiasales@bmjgroup.com

Visit casereports.bmj.com for more articles like this and to become a Fellow 